\title{
AN INVESTIGATION INTO THE ROLE OF LISTED PROPERTY SHARES IN A RETIREMENT FUND PORTFOLIO IN SOUTH Africa
}

\author{
Mkhethwa Mkhize \\ Wits Business School, University of Witwatersrand \\ Vuyani Bekwa \\ Independent researcher
}

\begin{abstract}
The main aim of this research paper was to investigate the role of listed property shares in a retirement fund portfolio in South Africa, one objective being to determine the appropriate weightings to be allocated to listed property shares. This research paper uses data collected from January 1995 to December 2004. The Elton and Gruber computer programme is used to test the data to give optimal weightings to the listed property sector and to produce an efficient frontier. The results of this research paper demonstrated the benefits offered by listed property shares and revealed that the sector should be treated as a separate asset class from equity owing to low correlation of returns between these two classes of assets. Results also demonstrated that an increase in the allocation to the listed property sector results in better investment performance over the study period.
\end{abstract}

Abstract

JEL G12, 23

\section{1 \\ Introduction}

Real estates are everyone's investment tools, whether in the form of home ownership or commercial use. Real estates are believed to be alternatives to other forms of investment assets. "These alternatives range from passive investments in companies that own and manage real properties to active investments in which the individual owns properties and rents the space" (Mayo, 2002: 767). Most scholars in favour of real estate investments anticipate two main benefits of investment in real estates, namely: diversification and inflation-hedged benefits. As an alternative to owning real estates, investors invest in shares of real estate investments trusts. These shares are "bought and sold like the stocks of other companies (Mayo, 2002: 784). It could therefore be inferred that portfolio/investment managers must invest either directly in real estate (property) or indirectly in real estate shares (listed property) in order to maximise benefits (in the form of diversification and inflation-hedging) of their investment portfolios.

However, the Alexander Forbes Large Manager Watch Survey (2004) shows that investment managers in South Africa have not recognised the full benefits offered by listed property, owing to the low allocation of funds to this sector. The I-Net Bridge (2004) database shows that listed property shares pay out a major portion of their income during periods of downward trends in capital markets. According to Chen and Mills (2004), any portion of total return that is achievable with greater certainty limits the potential downside of an investment and lowers the vulnerability of the investment returns to negative surprises. The implications are that listed property shares possess unique attributes that contribute directly to low riskiness of any portfolio.

Portfolio managers are constantly evaluated on how they perform, that is, the total return they achieve for the investor. An overriding 
objective on the part of a portfolio manager is therefore to maximise returns while minimising risk. Unfortunately, even though the portfolio manager might be aware of the risks, the returns from listed property have been more difficult to quantify because listed property in South Africa is poorly researched (Maritz \& Miller, 2004). These authors point out that academic research on the role of listed property in investment portfolios has received little attention, both internationally and locally. This implies that listed property will continue to be regarded as a neglected asset class as long as the latter is not researched with far more diligence. To achieve such an outcome, this paper attempts to investigate the role of listed property shares in a retirement fund portfolio in the South African context. The specific intention is to investigate some of the most important facets of the listed property sector, such as its relationship with equities, its portfolio risk-reduction ability and its general performance relative to equity.

2

\section{Literature review}

According to a report by Datamonitor (2004), Australia was one of the first countries to follow the United States' lead with the introduction in 1960 of real estate investment trusts (REITs). Canada followed suit, but only in the early 1990s. Reilly and Brown (2003) describe REITs as investment funds that hold portfolios of real estate investments. Table 1 (below) summarises the value and growth rates of REITs in the global market.

Table 1

Global real estate investment trusts sector value: 1999-2003

\begin{tabular}{|c|c|c|}
\hline Year & $\begin{array}{c}\text { Total value } \\
\text { (US\$ billions) }\end{array}$ & $\begin{array}{c}\text { Growth rate } \\
\text { (\%) }\end{array}$ \\
\hline 1999 & 167.5 & $\mathrm{n} / \mathrm{a}$ \\
\hline 2000 & 166.0 & -0.9 \\
\hline 2001 & 187.2 & 12.8 \\
\hline 2002 & 200.8 & 7.3 \\
\hline 2003 & 273.4 & 6.31 \\
\hline
\end{tabular}

Source: Datamonitor (2004) Global real estate investment trusts: Industry profile

Datamonitor's (2004) report shows that the REITs market in the United States, according to which many other countries have based their framework, dominates the global market, accounting for about 80 per cent of the global sector's value in 2003. In the United States (US), the Employee Income Security Act (ERISA) was passed in the mid-1970s to limit abuse in the pension fund world by creating a series of regulations to govern plan sponsor behaviour (Winograd \& McIntosh, 2002). According to Winograd and McIntosh (2002), ERISA was inspired by modern portfolio theory to promote prudent portfolio diversification in order to reduce overall risk and stimulate pension fund investment in property.
Hudson-Wilson, Fabozzi and Gordon (1990) identified four main reasons why a portfolio should be exposed to property. Firstly, overall risk-reduction of the portfolio would be accomplished by combining asset classes that respond differently from expected and unexpected market conditions. Secondly, it would achieve returns above the risk-free rate and deliver strong cash flows to the portfolio. In other words, this would improve risk-adjusted performance of a portfolio as measured by the Sharpe index. Thirdly, it would hedge against unexpected inflation, ensuring that the portfolio produces positive real returns. Finally, it would constitute part of a portfolio that is a reasonable reflection of the overall investment universe and the economy. 
According to a number of authors, investment management attention has shifted from an emphasis on asset allocation to a more balanced emphasis on diversification and the interrelationship of individual asset class characteristics within the portfolio. Karlberg, Crocker and Greig (1996) suggest that a 9 per cent allocation to real estate is optimal, rather than the 20 per cent figure suggested in other studies. Hoesli, Lekander and Witkiewicz (2003b) found that investing directly in offshore real estate reduced portfolio risk. In a study by Hoesli, Lekander and Witkiewicz (2004) and in support of Hoesli, Lekander \& Witkiewicz (2003a), property was found to be a very effective portfolio diversifier in seven countries on three continents over the 1987-2001 study period.

Other authors doubt the ability of property to reduce portfolio risk. For example, Glascock, Lu and So (2000) show that, from 1987 to1991, listed property was segmented from equity, but was co-integrated from 1992 to 1996. These authors argue that the benefits of including listed property in a multi-asset portfolio have diminished since 1992. Glascock et al. (2000) show that over their study period listed property was co-integrated with unsecuritised property. Their results suggest that the ability of listed property to reduce portfolio risk was reduced. On the other hand, Liang and McIntosh (1998) argue that the benefits of diversification from including listed property in a multi-asset portfolio increased after 1992. They conclude that the uniqueness of listed property as a risk diversifier is enhanced and listed property should form a significant part of any portfolio.

Tarbert (1966: 77) defines a perfect hedge against inflation as "an asset where the nominal returns perfectly co-vary with inflation". In general, property has been perceived as providing a hedge against inflation. Most research into the ability of property to hedge against inflation shows that, in the long run, property seems to provide a better hedge against inflation than does equity (Hoesli, 1994). Fraser, Leishman and Tarbert (2002: 354) suggest that there is a "low correlation between conventional gilts and property, as the former is inflation prone and the latter is generally viewed as an inflation hedge".
Given the four anticipated benefits of investing in listed property as reported by Hudson et al. (1990), this research paper attempts to carry out an investigation into the role of listed property shares in a retirement fund portfolio in South Africa. Specifically, it establishes the optimal allocation of listed property that would increase the returns of the portfolio.

\section{3}

\section{Research design}

\subsection{Data}

Data were collected from two electronic feed sources namely: I-Net Bridge and the JSE Securities Exchange on each of the different asset classes. These sources form part of reliable databases in South Africa. Proxies for asset classes were used to create a portfolio of mixed asset classes. Equities are represented by the JSE All Share Index. Bonds are represented by the 7-12 year (medium-term) bond index, the All Bond Index (ALBI). The reason for the use of the ALBI is that the modified duration ${ }^{1}$ of property is similar to that of medium-term bonds. Cash was used to represent a risk-free asset. Listed property is represented by the Property Unit Trust Index, the J255 index. Data used in this research paper consist of the weekly closing prices of well-established benchmarks, namely the market indices of the ALSI, the J255 and the ALBI for the ten-year period from January 1, 1995 to December 31, 2004. These data were downloaded from a reliable I-Net Bridge research database.

\subsection{Data manipulation}

Total returns are calculated for each different asset class. As reported by Msweli-Mbanga and Mkhize (2007), Affleck-Graves, Burt and Cleasby (1988) and Van den Honert, Barr and Smale (1988) share/index price returns $\left(\mathrm{R}_{\text {index }}\right)$ are computed using the following formula:

$\left(\mathrm{R}_{\text {index }}\right)=\left[\left(\frac{P_{1}-P_{0}}{P_{0}}\right) \times 100\right]$

Where: $P_{1}$ is the price of an index at the close of the last trading day in a week. $\mathrm{P}_{0}$ is the price of an index at the opening of the trading day 
in a week. Investment income is assumed to be incorporated in the market share price. That is semi-strong market efficiency.

The formula is adopted here in order to compute weekly index returns. Weekly returns of these indices were thereafter compounded to calculate an annualised return. All annualised returns were, in turn, averaged in order to obtain a single average return over the study period. Weekly returns were regressed each year in order to obtain standard deviations for that particular year. In addition, weekly returns of indices were regressed against each other to obtain their correlation coefficients over the study period.

\subsection{Research methodology}

After data manipulation, resultant data were fed into an investment management programme called the Elton and Gruber's Markowitz Module (the Investment portfolio, Version 1). This programme is used to produce the Markowitz Efficient Frontier. This module calculated covariances between indices (asset classes). After prompting for portfolio weightings (if any), the Elton and Gruber Module is ready to produce the Markowitz Efficient Frontier, which assists in determining optimal allocation weightings of listed property, as measured by the $\mathrm{J} 255$ index in this study. Prompting for weightings is a crucial step because it affords portfolio managers the opportunity of adhering to prudential investment guidelines, as different investors stipulate different policies and guidelines.

In order to construct a traditional portfolio, initial ALSI and ALBI weightings of 75 per cent and 25 per cent respectively are assumed. These maximum weightings are suggested by legislated prudential investment guidelines, which are intended to ensure a conservative investment spread for retirement funding products in order to protect the investor from loss of value due to risky investment selection. Furthermore, prudential investment guidelines state that the weightings to listed property should be limited to 25 per cent. This weighting of 25 per cent to listed property is fed into Elton and Gruber's Markowitz Module in order to determine the role listed property may play in a retirement fund portfolio.

However, the Elton and Gruber Markowitz Module will recommend weightings of an optimised portfolio without stating the anticipated performance of such a portfolio. In order to do that, the risk-adjusted performance of both traditional and optimised portfolios is computed using the Sharpe index. Fabozzi (1999) argues that the Sharpe index is a measure of the reward-to-risk ratio, and that the risk of the asset is measured by the standard deviation (SD) of that asset. As reported by MsweliMbanga and Mkhize (2007), Mayo (2005) states that the Sharpe index (SI) is given as follows:

$\mathrm{SI}=\frac{\left(R_{i}-R_{f}\right)}{S D_{i}}$

where $\mathrm{R}_{\mathrm{i}}$ is the average return of the J255, ALSI or ALBI index. $R_{f}$ is the return received from investing in a risk-free asset. Cash is a proxy for a risk-free asset in this research paper. SDi is the standard deviation of the J255, ALSI or ALBI index.

The higher the Sharpe index, the better the risk-adjusted performance of a variable under consideration.

\section{4 \\ Research results}

Annualised returns of indices over the study period are presented in Table 2 below.

Table 2

Annualised returns of indices: 1995-2004

\begin{tabular}{|c|c|c|c|c|}
\hline Year & $\begin{array}{c}\mathbf{J 2 5 5} \\
\mathbf{( \% )}\end{array}$ & $\begin{array}{c}\text { ALSI } \\
\mathbf{( \% )}\end{array}$ & $\begin{array}{c}\text { ALBI } \\
\mathbf{( \% )}\end{array}$ & $\begin{array}{c}\text { Cash } \\
\mathbf{( \% )}\end{array}$ \\
\hline 1995 & 12.05 & 13.93 & 36.39 & 13.38 \\
\hline 1996 & -11.34 & 3.35 & 3.65 & 16.31 \\
\hline
\end{tabular}




\begin{tabular}{|l|c|c|c|c|}
\hline 1997 & 22.94 & -5.80 & 30.58 & 17.22 \\
\hline 1998 & 3.67 & -5.91 & 3.38 & 17.79 \\
\hline 1999 & 55.99 & 70.56 & 31.18 & 15.72 \\
\hline 2000 & 27.64 & -0.05 & 20.97 & 10.95 \\
\hline 2001 & 8.15 & 30.55 & 20.38 & 10.61 \\
\hline 2002 & 22.80 & -6.62 & 16.20 & 11.53 \\
\hline 2003 & 40.22 & 13.91 & 21.11 & 12.78 \\
\hline 2004 & 41.78 & 24.85 & 17.91 & 8.22 \\
\hline
\end{tabular}

Annual standard deviations of indices over the study period are depicted in graph 1 below.

Graph 1

Standard deviations of indices

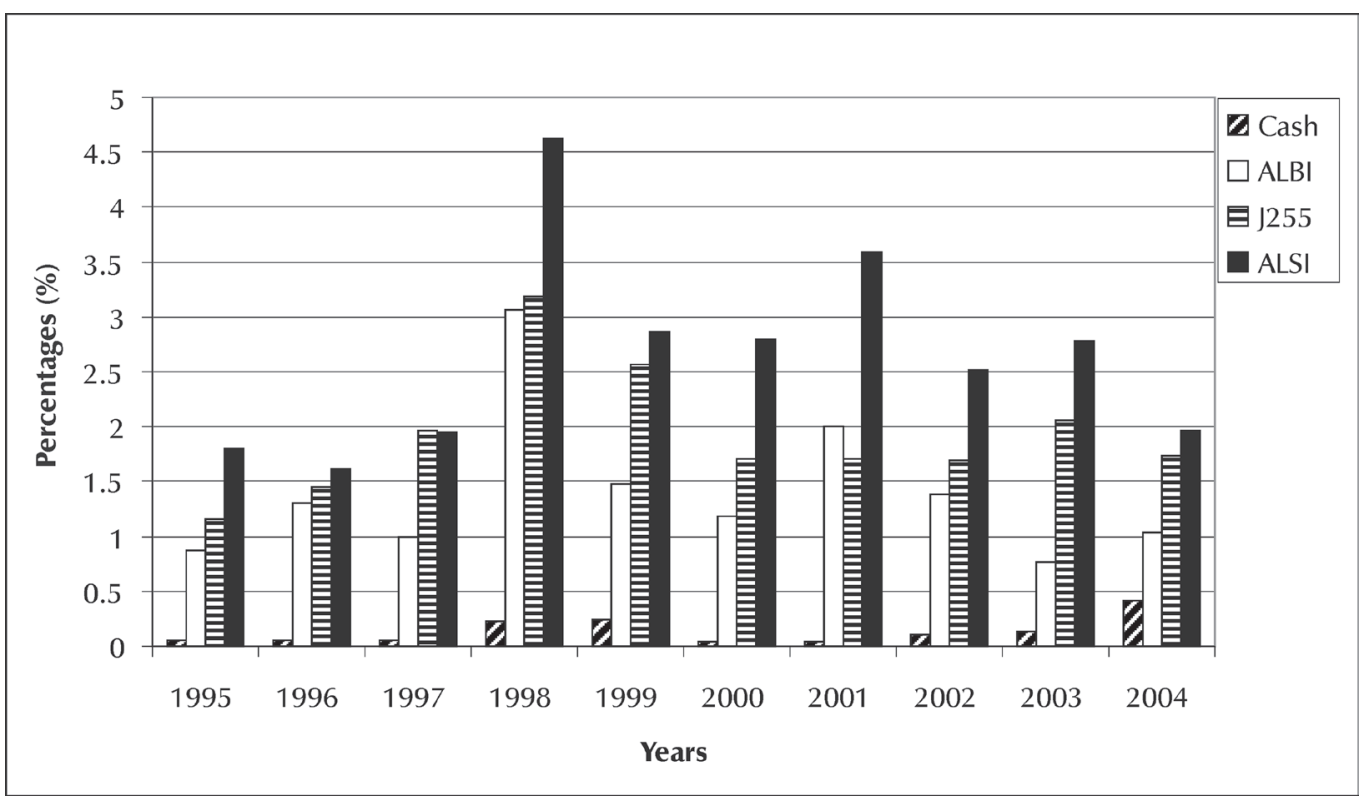

Table 3 (below) shows averaged returns of covariances between indices over the study indices, as well as correlation coefficients and period.

Table 3

Averaged returns of, correlation co-efficients and covariances between indices: 1995-2004

\begin{tabular}{|l|c|c|c|c|}
\hline \multicolumn{1}{|c|}{ Variable } & $\begin{array}{c}\mathbf{J 2 5 5} \\
\mathbf{( \% )}\end{array}$ & $\begin{array}{c}\text { ALSI } \\
\mathbf{( \% )}\end{array}$ & $\begin{array}{c}\text { ALBI } \\
\mathbf{( \% )}\end{array}$ & $\begin{array}{c}\text { Cash } \\
\mathbf{( \% )}\end{array}$ \\
\hline Total returns & 22.39 & 13.88 & 20.18 & 13.45 \\
\hline Standard deviations & 19.11 & 22.62 & 10.33 & 3.04 \\
\hline
\end{tabular}




\begin{tabular}{|c|c|c|c|c|}
\hline \multicolumn{5}{|c|}{ Correlation co-efficients } \\
\hline & $\begin{array}{c}J 255 \\
(\%)\end{array}$ & $\begin{array}{l}\text { ALSI } \\
(\%)\end{array}$ & $\begin{array}{c}\text { ALBI } \\
(\%)\end{array}$ & $\begin{array}{c}\text { Cash } \\
(\%)\end{array}$ \\
\hline $\mathrm{J} 255$ & 100 & 58.2 & 53.4 & -32.4 \\
\hline ALSI & 58.2 & 100 & 41.8 & -13.4 \\
\hline ALBI & 53.4 & 41.8 & 100 & -12.9 \\
\hline Cash & -32.4 & -13.4 & -12.9 & 100 \\
\hline \multicolumn{5}{|l|}{ Covariances } \\
\hline & $\begin{array}{c}J 255 \\
(\%)\end{array}$ & $\begin{array}{c}\text { ALSI } \\
(\%)\end{array}$ & $\begin{array}{c}\text { ALBI } \\
(\%)\end{array}$ & $\begin{array}{c}\text { Cash } \\
(\%)\end{array}$ \\
\hline$J 255$ & 3.65 & 2.51 & 1.05 & -0.19 \\
\hline ALSI & 2.51 & 5.12 & 0.98 & -0.09 \\
\hline ALBI & 1.05 & 0.98 & 1.07 & -0.04 \\
\hline Cash & -0.19 & -0.09 & -0.04 & 0.09 \\
\hline \multicolumn{5}{|c|}{ Traditional portfolio } \\
\hline Asset class & $\begin{array}{c}\text { Weightings } \\
(\%)\end{array}$ & $\begin{array}{l}\text { Historical } \\
\text { returns (\%) }\end{array}$ & $\begin{array}{l}\text { Weighted } \\
\text { returns (\%) }\end{array}$ & \\
\hline ALSI & 75 & 13.88 & 10.41 & \\
\hline ALBI & 25 & 20.18 & 5.05 & \\
\hline Total portfolio & & & 15.46 & \\
\hline \multicolumn{5}{|c|}{ Optimal portfolio } \\
\hline Asset class & $\begin{array}{c}\text { Weightings } \\
(\%)\end{array}$ & $\begin{array}{l}\text { Historical } \\
\text { returns (\%) }\end{array}$ & $\begin{array}{l}\text { Weighted } \\
\text { returns (\%) }\end{array}$ & \\
\hline $\mathrm{J} 255$ & 12 & 22.39 & 2.69 & \\
\hline ALSI & 13 & 13.88 & 1.80 & \\
\hline ALBI & 75 & 20.18 & 15.14 & \\
\hline Total portfolio & 100 & & 19.63 & \\
\hline
\end{tabular}

Table 4 (below) presents the risk-adjusted performance of the market indices used over the study period.

\section{Table 4}

Sharpe indices of indices: 1995-2004

\begin{tabular}{|l|c|c|c|}
\hline \multicolumn{1}{|c|}{ Variable } & $\begin{array}{c}\text { Standard deviation } \\
\mathbf{( \% )}\end{array}$ & $\begin{array}{c}\text { Average return } \\
\mathbf{( \% )}\end{array}$ & $\begin{array}{c}\text { Sharpe index } \\
\mathbf{( \%}\left(\mathbf{R}_{\mathbf{i}}-\mathbf{R}_{\mathbf{f}}\right) / \mathbf{S D}_{\mathbf{i}}\end{array}$ \\
\hline J255 & 19.11 & 22.87 & 0.47 \\
\hline ALSI (market) & 22.92 & 13.88 & 0.02 \\
\hline ALBI & 10.33 & 20.18 & 0.65 \\
\hline Cash (risk-free) & $0 *$ & 13.45 & not applicable \\
\hline
\end{tabular}

* The standard deviation of cash is assumed to be zero because it is generally accepted as a risk-free asset. 
5

\section{Discussion and conclusions}

According to Table 2, the yearly property returns ranged from -11.34 per cent in 1996 to 55.99 per cent in 1999. Equity returns ranged from -6.62 per cent in 2002 to 70.56 per cent in 1999. In the case of bonds, yearly returns were at the highest rate of 36.39 per cent in 1995 , slumping to a low of 3.38 per cent in 1998. The risk-free rate was at its highest point of 17.79 per cent in 1998 and reached the lowest rate of 8.22 per cent in 2004 . Over the study period, the highest rate achieved by any asset class was 70.56 per cent, realised in the equity market in 1999 . The lowest rate (highest loss) of -11.34 per cent was experienced by the property market in 1996 .

Graph 1 shows that listed property experienced the highest risk (standard deviation) of 3.18 per cent in 1998 and the lowest risk of 1.15 per cent in 1995. In the equity market, the highest level of volatility was at 4.63 per cent in 1998 and the lowest level of risk (1.61 per cent) was achieved in 1996. In the bond market, risk reached its lowest level of 0.76 per cent in 2003 and was at its highest level of 3.07 per cent in 1998. Graph 1 also shows that the highest risk recorded for cash is 0.42 per cent in 2004 . This risk level may be immaterial to investors who regard cash as a risk-free asset.

As expected, the higher level of nominal returns realised in the equity market is accompanied by a high level of risk. For example, the period from 1995 to 1996 shows a low level of risk, and from 1998 to 1999 there is a high level of risk. Nominal returns are at their highest during the 1998 to 1999 period and, on average, at their lowest over the 1995 to 1996 period. Because the risk-free rate is high over the 1998 to 1999 period, the equity market risk premium is not increased over the 1998 to 1999 period. Consequently, the performance of the equity market is not superior over the 1998 to 1999 period. In conclusion, the result of this study suggests that the 1995 to 1996 period was the low-risk period on the South African capital market. On the other hand, highest levels of risk were experienced across the combined South African capital market from 1998 to 1999.
Generally, bonds are less risky than equities, which is why an initial weighting to equity is limited to 75 per cent. This is in accordance with legislated investment guidelines intended to protect the investor from loss of value due to risky investment selection. When constructing a traditional portfolio comprising only bonds and equity, and limiting weightings to equity to 75 per cent as mandated on the investment guidelines for a retirement fund industry in South Africa, the total return of 15.46 per cent is realised. However, when listed property is taken into account and investment guidelines for a retirement fund industry which includes this asset class in a portfolio are adhered to, different sets of results are realised. The Elton and Gruber's Markowitz Module is used to compute optimal portfolio weightings.

Results of this programme show that the exposure to the listed property should be 12.41 per cent (approximately 12 per cent), while the ALSI exposure should be 12.589 per cent (approximately 13 per cent). According to the programme, the highest exposure to bonds should be 75 per cent. This research paper uses these recommendations to calculate new total return of an optimised portfolio according to the Elton and Gruber Markowitz Module. Results displayed in Table 4 (above) indicate that total returns of a portfolio increase from 15.46 per cent to 19.63 per cent. Elton and Gruber's Markowitz Module's results also show that the security market line of an efficient frontier, given the above-mentioned weightings, starts at 13.45 per cent. This risk-free rate of 13.45 per cent therefore represents the compounded cash returns over the study period of this research paper.

However, rates of return, discussed above, are simply market-risk premiums. In order to make economic sense and to indicate the role of listed property in a retirement fund portfolio, Sharpe indices of both the traditional and optimised portfolios are computed. Table 4 presents the Sharpe indices of the listed property sector, equity market and bonds market. Results shown in this table indicate that the bond market yields the highest returns on a risk-adjusted basis, followed by listed property and then the equity market. In fact the equity market realised a loss 
of 6.1 per cent on a risk-adjusted basis over the study period.

Table 3 also shows the correlation co-efficient between indices. These results show that the correlation co-efficient between the equity market and listed property sector of 0.582 is larger than the correlation co-efficient between the listed property sector and the bonds market. As a result, it would be more profitable to combine listed property assets with debt owing to low correlation than it would be to combine listed property assets with equity. Results also show that most diversification benefits (illustrated by lower correlation co-efficient) will be realised when combining equity with debt in a portfolio. This is also supported by the low risk associated with bonds or higher Sharpe index of bonds. These correlation co-efficient results (in Table 4) are in support of risk-adjusted performance (refer Table 4) of a portfolio consisting mostly of bonds and listed property, as suggested by the Markowitz Module.

In conclusion, the Sharpe index of the listed property sector is higher than that of the equity market; and the correlation coefficient between the listed property sector and the equity market is approximately 0.5 . These results support the hypothesis that listed property presents unique attributes, different from those presented by the equity market. These results also suggest that listed property contributes significantly in a positive way to the performance of a retirement fund industry in South Africa. In other words, listed property plays a positive role in the riskadjusted performance of a retirement fund portfolio in South Africa.

Future research may focus on the qualitative factors that fund managers consider when investing or not in listed property.

\section{Endnote}

1 "Duration is a measure of the average (cashweighted) term-to-maturity of a bond. There are two types of duration, Macaulay duration and modified duration. Macaulay duration is useful in immunisation, where a portfolio of bonds is constructed to fund a known liability. Modified duration is an extension of Macaulay duration and is a useful measure of the sensitivity of a bond's price to interest rate movements", author unknown [online] (http://www.finpipe.com/duration.htm) [accessed 16 February 2008.]

\section{References}

AFFLECK-GRAVES, J.F.; BURT, G.H. \& CLEASBY, S.J.M. 1988. The premium on acquisition in South African mergers: An empirical evaluation. South African Journal of Business Management, 19(4): 55-160. ALEXANDER FORBES LARGE MANAGER WATCH ANNUAL SURVEY, 2004. African Harvest joins the ranks of large managers, [online] URL:http:// www.africanharvest.co.za/shared/news/A_Quarter_ Past/A_Quarter_Past_Mar_2004.pd CHEN, L. \& MILLS, T. 2004. Global real estate investment going mainstream, UBS Real Estate Research, [online]. URL:http://www.irei.com/ uploads/ marketresearch/ 55/ marketResearchFile/Global_Real_ Estate.pdf.

DATAMONITOR. 2004. [online] URL:http://www. marketresearch.com/browse. asp? categoryid $=161 \&$ sor tby $=\mathrm{t} \& \mathrm{~g}=1 \&$ page $=7$.

FABOZZI, F.J. 1999. Investment management ( $2^{\text {nd }}$ ed. $)$, New Jersey: Prentice-Hall.

FRASER, W.D., LEISHMAN, C. \& TARBERT, H. 2002. The long-run diversification attributes of commercial property. Journal of Property Investment and Finance, 20(4): 354-373.

HOESLI, M. 1994. Real estate as a hedge against inflation: Learning from the Swiss Case. Journal of Property Valuation and Investment, 12(3): 51-59. HOESLI, M., LEKANDER, J. \& WITKIEWICZ, W. 2003a. Further evidence on the integration of REIT, bond and stock returns. The Journal of Real Estate Finance and Economics, 20(2): 177-194.

2003b. Real estate in the institutional portfolio: A comparison of suggested and actual weights. Journal of Alternative Investments, 6(2): 55-59. 2004. International evidence on real estate as

portfolio diversifier. Journal of Real Estate Research, 26(2): 161-207.

HUDSON-WILSON, S., FABOZZI, F.J. \& GORDON, W. 1990. Why real estate? Journal of Portfolio Management, Special real estate issue, September: 12-27.

I-NET BRIDGE, 2004. [online] URL: http://iis-host1. inet.co.za/intrahosted/I-Net/JSEIndicesNewWeb.htm. LIANG, Y. \& MCINTOSH, W. 1998. REIT style and performance. Journal of Real Estate Management, 4: 39-47.

MARITZ, J. \& MILLER, K. 2004. Property - a neglected asset class: a quantitative survey of listed and directly-held property in South Africa. Cadiz Financial 
Services, February, [online] URL:http://www.cadiz. co.za/bo/ assetmanagement/overview.asp. MAYO, H.B. 2002. Investments ( $8^{\text {th }}$ ed.) Ohio: Thomson South-Western.

MSWELI-MBANGA, P. \& MKHIZE, H.M.A. 2007. The risk-adjusted performance of companies with female directors: A South African case. South African Journal of Economic and Management Sciences, 10(2): 207-213.

REILLY, F. \& BROWN, K. 2003. Investment Analysis and Portfolio Management ( $8^{\text {th }}$ ed.). Mason: McGrawHill.
TARBERT, H. 1996. Is commercial property a hedge against inflation? A cointegration approach. Journal of Property Finance, 7: 77-98.

VAN DEN HONERT, R.C, BARR, G.D.I. AFFLECKGRAVES, J.F. \& SMALE, G. 1988. Merger

announcements and share price return -The role of the relationship between acquiring and target firms. South African Journal of Business Management, 19(1): 1-10. WINOGRAD, B. \& MCINTOSH, W. 2002. Revisiting the case for including real estate in a mixed-asset portfolio. Journal of Real Estate Portfolio Management, 3: $107-115$ 